Not all of the types of symmetry enumerated in this table are available as types of crystal symmetry, for the law of rational indices limits the acceptable axes of symmetry to those of the orders $2,3,4,6$. With this limitation the table furnishes the 32 types of crystal symmetry, 11 from each of the first two columns and 10 from the third.

New YoRK.

December 4, 1910.

\title{
HORNER'S METHOD OF APPROXIMATION ANTICIPATED BY RUFFINI.
}

\author{
BY PROFESSOR FLORIAN CAJORI.
}

(Read before the Southwestern Section of the American Mathematical Society, November 26, 1910.)

BEFORE the nineteenth century no simple elementary practical process was known of computing the coefficients of an equation whose roots are less by a given constant than the roots of a given affected numerical equation $f(x)=0$. Such a process was invented in the early part of the last century and is contained in the so-called "Horner's method of approximation."

The history of Horner's method, as developed in England, has been traced in detail by Augustus De Morgan.* $\mathrm{He}$ quotes extensively from original sources and shows that, of English rivals (among whom were Theophilus Holdred, Peter Nicholson, and Henry Atkinson), none except perhaps Nicholson advanced methods of approximation that equalled Horner's, and none was entitled to priority over Horner. It is wellknown that the popularization of Horner's process of approximation in England was due to De Morgan and J. R. Young. Except for the efforts of these men, Horner's paper of 1819 in the Philosophical Transactions might have been lost sight of and forgotten. De Morgan was an enthusiast on Horner's method. He taught it with great zeal ; he made sport of Cambridge tutors who were not familiar with it $\nmid \dagger$ the preparation of his historical tract, alluded to above, was evidently a labor

\footnotetext{
* Companion to the [British] Almanac for 1839, Art. "Notices of the progress of the problem of evolution," pp. 34-52.

$\dagger$ A. De Morgan, A Budget of Paradoxes, London, 1872, pp. 292, 375.
} 
of love. It is still the standard reference to early English research on the subject. That Horner had a rival claimant outside of England, De Morgan never suspected.*

It is the purpose of this paper to show that fifteen years before the publication of Horner's first paper $\dagger$ an almost identical method was published in Italy by Paolo Ruffini, whose name is usually associated with the proof of the impossibility of solving algebraically the quintic equation. Ruffini had no J. R. Young and no De Morgan to urge upon the mathematical public the importance of his method of approximation. The method was overlooked, and now, over a century later, begins the weary process of the "restitution of decayed intelligence."

In 1802 the Italian Scientific Society (of Forty) offered a gold medal for the best method of determining the roots of a numerical equation of any degree. Five dissertations were submitted in competition and in 1804 the medal was awarded to Paolo Ruffini. The dissertation was published by the Society in an unwieldy, large quarto monograph of 175 pages, bearing the title:

"Sopra la determinazione delle radici nelle equazioni numeriche di qualunque grado. Memoria del Dottor Paolo Ruffini, pubblico professore di matematica sublime in Modena, uno dei quaranta della società italiana delle scienze ec. Coronata dalla società medesima. In Modena, mDcccrv. Presso la società tipografica. Con Approvazione."

Ruffini wrote on the subject of approximation again in $1807 \ddagger$ and $1813 . \S$ In these later articles he gave a simpler exposition of the method and explained its application to the extraction of roots of numbers.

While Horner had no knowledge of Ruffini's publications on

* Budget of Paradoxes, p. 375.

† Horner prepared three important papers on his method of approximation: (1) "A new method of solving numerical equations of all orders, by continuous approximation," Philosophical Transactions (London), 1819, Part I, pp. 308-335; (2) An article in Leybourn's Mathematical Repository, Vol. 5, Part 2, No. 19, London, 1830 ; Extracts from this are given in J. R. Young's Theory and Solution of Algebraical Equations, London, 1813, pp. 474, 475 ; (3) "On algebraic transformation," The Mathematician, Vol. I, London, 1845 , p. 109.

† Algebra elementare del Dottor Paolo Ruffini, Modena, MDcccvir, Capo $I V, V$, and in an Appendice which is not in my copy of this Algebra and seems to have been bound separately and published in 1808 .

$\S$ "Di un nuovo metodo generale di estrarre le radici numeriche." Memoria del Signor Cav. Paolo Ruffini. Memorie di Matematica e di Fisica della Societa Italiana delle Scienze. Tomo XVI, Parte I. Verona, MDcccxIII, pp. 373-429; Tomo XVIr, parte contenente del memorie di matematica, pp. 1-15. 
the approximation to the roots of equations, Horner's papers of 1819 and 1845 contain nevertheless some interesting parallelisms to Ruffini's publications of 1804,1807 , and 1813 .

In their first publications both authors used the differential calculus in expounding their methods; Ruffini used ordinary derivatives, Horner used Arbogast's derivatives.

In later publications both authors gave simplified explanations of their methods, dispensing with the calculus and using ordinary algebra. Ruffini's simplified exposition appeared in 1807 and 1813 ; Horner's in 1845 as a posthumous article.*

Both authors pointed out that the methods could be used with advantage in the root-extraction of numbers. Ruffini laid greater stress on this point than did Horner ; in fact, Ruffini's publications of 1807 and 1813 consider the process from this point of view alone. Neither author extended the method of approximation so as to render it applicable to the determination of complex roots.

A contrast between the two authors lies in the fact that Horner in 1819 erroneously believed that his method was at once applicable to irrational and transcendental equations. He says : "From the unrestricted nature of the notation employed, it is evident that no class of equations, whether finite, irrational, or transcendental, is excluded from our design." $\dagger \mathrm{He}$ gives no other argument nor any illustrative solutions of irrational or transcendental equations, in support of his claim. Ruffini, on the other hand, confined his discussion to rational integral algebraic equations.

A second contrast is this, that Horner in his paper of 1830 carefully explains a special procedure in his method, by which two nearly equal real roots can be separated with certainty. Ruffini never considered this refinement of the method.

To explain Ruffini's method of approximation, we quote from pages $22-25$ of his memoir of 1804 . The equation $(A)$, referred

* This article of 1845 had been read before the Royal Society, June 19, 1823 , but (as T. S. Davies explains in an introductory note to the printed paper) was refused publication in the Philosophical Transactions, even after it had been considerably curtailed. Horner of ten stated to Davies that much demur was made to the insertion of his first paper in the Philosophical Transactions. "The elementary character of the subject," says Davies, "was the professed objection : his recondite mode of treating it, was the professed passport for its admission." Horner's third article was a simplification of the principles of his process. In this article he says of Budan, I am "satisfied with finding that he had not anticipated my discovery."

$\dagger$ Philosophical Transactions, 1819, Part I, pp. 317, 318. 
to in the quotation, is as follows:

$$
A x^{m}+B x^{m-1}+C x^{m-2}+\text { ec. }+S x^{2}+T x+V=0 .
$$

"Supposto $x=p+y$, determinare un metodo spedito, onde trasformare 1' Equazione $(A)$ in un' altra con l' incognita $y$.

"Dalle proprietà delle trasformate sappiamo, che, essendo $Z$ il primo membro della $(A)\left(\mathrm{n} .^{\circ} 1\right)$, la trasformata richiesta si ottiene ponendo $p$ in luogo di $x$ nella

$$
Z+\frac{d Z}{d x} y+\frac{d d Z}{2 d x^{2}} y^{2}+\frac{d^{3} Z}{2 \cdot 3 d x^{3}} y^{3}+\text { ec. }+A y^{m}=0
$$

Ora pel (n. $\left.{ }^{\circ} 10\right)$ nella ipotesi di $x=p$ abbiamo $Z=P^{(m+1)}$, e quindi

$$
\begin{aligned}
\frac{d Z}{d x}=\frac{d P^{(m+1)}}{d p}=Q^{(m)}\left(\mathrm{n} .^{\circ} 8\right), \quad \frac{d d Z}{2 d x^{2}} & =\frac{d Q^{(m)}}{2 d p}=R^{(m-1)}, \\
& \frac{d^{3} Z}{2 \cdot 3 d x^{3}}=\frac{d R^{(m-1)}}{3 d p}=S^{(m-2)}, \text { ec. }
\end{aligned}
$$

Dunque queste quantità $P^{(m+1)}, Q^{(m)}, R^{(m-1)}, S^{(m-2)}$, ec. altro non sono che i coefficienti della Equazione in $y$, ed essa sarà perciò la seguente

$$
\text { (F) } P^{(m+1)}+Q^{(m)} y+R^{(m-1)} y^{2}+S^{(m-2)} y^{3}+\text { ec. }+A y^{m}=0 \text {. }
$$

"Ciò essendo, per isciogliere il nostro Problema, altro non dovremo, che determinare speditamente le quantità $P^{(m+1)}, Q^{(m)}$, $R^{(m-1)}, S^{(m-2)}$, ec.

"A tal fine disposti in $(I V)$ i coefficienti della $(A)$ nel modo istesso del (I) (n. $\left.{ }^{\circ} 9\right)$, e determinate nella maniera medesima tutte le quantità $A, P^{\prime \prime}, P^{\prime \prime \prime}$, ec. $P^{(n+1)}$, colloco in una terza riga sotto della $P^{\prime \prime}$ il coefficiente $A$, moltiplico questo per $p$, sommo il prodotto $A p=Q^{\prime} p\left(2^{\circ} \cdot \mathrm{n} .^{\circ} 8\right)$ col sovrapposto $P^{\prime \prime}$, e il risultato $Q^{\prime} p+P^{\prime \prime}$, essendo pel cit. ${ }^{\circ}\left(2^{\circ} \cdot \mathbf{n}^{\circ} \cdot 8\right)=Q^{\prime \prime}$, si ponga nella terza linea sotto dell termine $P^{\prime \prime \prime}$. Si moltiplici questo $Q^{\prime \prime}$ per $p$, si unisca con $P^{\prime \prime \prime}$, e pongasi sotto del $P^{I V}$ il risultato $Q^{\prime \prime} p+P^{\prime \prime \prime}=Q^{\prime \prime \prime}\left(2^{\circ} \cdot \mathrm{n}^{\circ} \cdot 8\right)$. Proseguendo così ad operare, otterremo sotto del $P^{(m+1)}$ il risultato $Q^{(m)} \ldots$. 


$$
\begin{aligned}
& A, B, C, \quad D, E, \quad F, \quad \text { ec. } V \text {, } \\
& A, P^{\prime \prime}, P^{\prime \prime \prime}, P^{\mathrm{Iv}}, P^{\mathrm{v}} \text {, ec. } P^{(m)}, P^{(m+1)} \text {, } \\
& A, Q^{\prime \prime}, Q^{\prime \prime \prime}, Q^{\mathrm{IV}}, \text { ec. } Q^{(m-1)}, Q^{(m)} \text {, } \\
& A, \quad R^{\prime \prime}, \quad R^{\prime \prime \prime}, \text { ec. } R^{(m-2)}, R^{(m-1)} \text {, } \\
& A, \quad S^{\prime \prime}, \text { ec. } S^{(m-3)}, S^{(m-2)} \text {, } \\
& A \text {, ec. } T^{(m-4)}, T^{(m-3)} \text {, } \\
& \text { ec. }
\end{aligned}
$$

"Nell' ultima $(m+1)$ esima colonna verticale contenendosi i valori dei coefficienti della $(F)$, li sostituisco nella $(F)$ medesima, e per tal guisa otterremo la trasformata richiesta con operazioni semplici, e facili ad eseguirsi, come ognuno può agevolmente vedere da se, e come apparisce dall' esempio seguente.

"Data la $4 x^{5}-6 x^{4}+3 x^{3}-5 x^{2}-4 x+8=0$, vogliasi trasformare in un' altra, nella quale sia $y=x-6$. Opero nel modo ora esposto,

$$
\begin{array}{rrrrrr}
4, \quad-6, & 3, & -5, & -4, & 8, & \\
4, & 18, & 111, & 661, & 3962, & 23780 \\
& 4, & 42, & 363, & 2839, & 20996 \\
& & 4, & 66, & 759, & 7393 \\
& & & 4, & 90, & 1299 \\
& & & 4, & 114 \\
& & & & & 4
\end{array}
$$

e otterremo la trasformata

$$
4 y^{5}+114 y^{4}+1299 y^{3}+7393 y^{2}+20996 y+23780=0 . "
$$

It appears from this that the computation demanded by Ruffini is identical with that in the familiar process of Horner. But the arrangement of the figures is different. The coefficients of the transformed equation appear, with Ruffini in the column on the extreme right, with Horner along a diagonal line slanting upward from left to right. It is not evident that, of the two arrangements, one possesses any marked superiority over the other. On pages 77-79 Ruffini computes the real root of Newton's cubic, $x^{3}-2 x-5=0$, to eight decimal places.

Ruffini in 1804 elaborated "Horner's method" of approximation to the roots of numerical equations with a clearness and thoroughness not surpassed in Horner's own exposition of 1819. In view of this fact, does not historical justice demand that the name of Ruffini be associated with that of Horner in 
the designation of the method? Why not call it the "RuffiniHorner method"?

It should be stated here that Budan, in his famous pamphlet of $1807, *$ explained a process of transformation of an equation into another whose roots are diminished by $h$, which bears some resemblance to that of Ruffini and Horner. When the roots are to be diminished by unity, the computation is identical. But when a root is to be diminished by, say 8 , there is a difference: Budan does this by eight steps, the roots being diminished by unity in each step. Regarding Budan, Ruffini once wrote to Delambre, the secretary of the French Institute, as follows : $\dagger$

"Troppo giuste sono le lodi che Ella dà al metodo del Sig. Budan di sciogliere le Equ. numeriche; avrei però desiderato che avesse Ella avuta occasione di vedere la Memoria che sopra lo stesso argomento presentai già alla nostra Società Italiana, che da essa riportò graziosamente il premio e che fu poi stampata nel 1804 fuori degli Atti. Coincido col sig. Budan nella maniera di fare le trasformazioni successive e nel servirmi dei decimali."

\section{THE NEW HAVEN COLLOQUIUM LECTURES.}

\section{The New Haven Colloquium. By Eurakim Hastings Moore,} Ernest Julius Wilczynski, Max Mason. Yale University Press, $1910 . \mathrm{x}+222 \mathrm{pp}$.

THE fifth Colloquium of the American Mathematical Society was held at New Haven, September 5-8, 1906, under the auspices of Yale University. All the lectures related to fields in which recent progress has been considerable, and were given by men who have made important contributions ; on this account the volume which contains the lectures should be of substantial interest, particularly to the American mathematician. Professor Moore gives a first systematic account of what he has termed "a form of General Analysis." Professor Wilczynski outlines the point of view and some of the principal results in

\footnotetext{
* F. D. Budan, Nouvelle méthode pour la résolution des équations numériques, Paris, 1807, pp. 14, 15, 29, 39.

$\dagger$ Memorie della Societa Italiana delle Scienze (detta dei XL), Serie $3^{a}$, Tomo XIV, 1906, p. 296.
} 